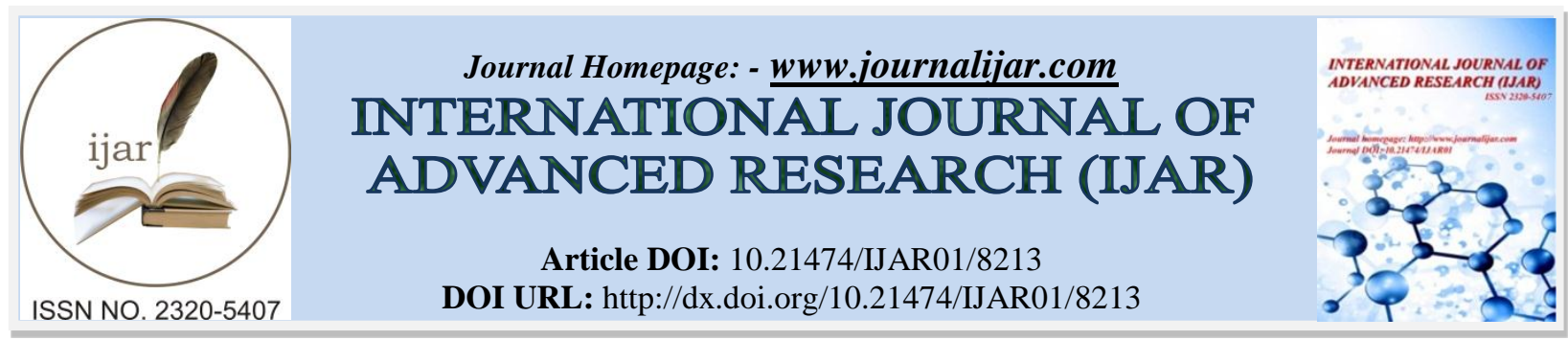

RESEARCH ARTICLE

\title{
A STUDY TO COMPARE THE EFFECTIVENESS IN REDUCTION OF PAIN LEVEL BETWEEN SIMPLE INTRAVENOUS CANNULATION AND PRO-SAFETY INTRAVENOUS CANNULATION.
}

\section{Sachi J. Christian' ${ }^{1}$ and Anil Sharma ${ }^{2}$.}

1. M.sc. Nursing, manikaka topawala institute of nursing -charusat, changa, ta. Petlad, dist. - anand, gujarat388421.india.

2. Principal and hod of medical surgical nursing, manikaka topawala institute of nursing -charusat, changa, ta. Petlad, dist. - anand, gujarat- 388421.india.

\section{Manuscript Info}

..........................

\section{Manuscript History}

Received: 16 October 2018

Final Accepted: 18 November 2018

Published: December 2018

\section{Keywords:}

Effectiveness, reduction of pain level, simple intravenous cannulation, prosafety intravenous cannulation, numerical rating scale.

\begin{abstract}
The word pain is derived from the Latin word 'poena' which means punishment, which in turn derived from the Sanskrit root 'pu' meaning purification. Pain is complex, multidimensional experience. A study to compare the effectiveness in reduction of pain level between simple intravenous cannulation and pro-safety intravenous cannulation. The study was conducted at selected hospitals of Anand district, Gujarat. A sample of 60 patients were selected using Non probability purposive sampling technique and randomly assigned into two groups. A Numerical rating scale was used by the investigator for data collection. The findings of the study illustrate that in simple IV cannula majority of the participants 25 ( $83.3 \%$ ) were having moderate pain, 5 (16.7\%) were having mild pain and the mean pain score is 4.3. In pro safety IV cannulation majority of the participants 24 ( $80 \%$ ) were having mild pain, only $6(20 \%)$ were having moderate pain and mean pain score is 2.67. Unpaired $\mathrm{t}$ calculated value is $6.49 * \mathrm{p}<0.05$ is significant at $0.05 \%$ level. This indicates that the pro safety IV cannulation is effective in reducing pain compare to simple IV cannulation. Calculated chi square value was less than the chi square tabulated value at 0.05 level of significance for all the selected demographic variables, hence it conclude that there is no significant association between simple IV cannulation and pro safety IV cannulation pain and demographic variables of selected patients.
\end{abstract}

Copy Right, IJAR, 2018,. All rights reserved.

\section{Introduction:-}

"Pain is such an uncomfortable feeling that even a tiny amount of it is enough to ruin every enjoyment". Will Rogers.

The word pain is derived from the latin word 'poena' which means punishment, which in turn derived from the Sanskrit root 'pu' meaning puification. The international association for the study of pain defines, "pain is an unpleasant sensory and emotional experience associated with actual or potential tissue damage, are described in terms of such damage". It further states that, "pain is subjective. ${ }^{1}$ Pain is a complex, multidimensional experience. ${ }^{2}$ 
Peripheral veins are the most common intravenous access method in both hospitals and paramedic services for a peripheral intravenous cannulation for intravenous therapy. ${ }^{3}$

Evidence has demonstrated that pain from IV cannulation is a significant source of adult pain and distress with effects far more reaching than the presenting event. When describing worse pain experiences in hospitalized adult, IV cannulation pain was found second reason in hospitalized patient. It is important to mitigate or decrease adult IV cannulation pain and distress in hospitalized patients. ${ }^{4}$

\section{Need for the study}

Pain is considered as $5^{\text {th }}$ vital sign in initial assessment of patients during hospitalization. Pain is a universal human experience and it is significant fear of most of the patient. The fear of pain is ranked only second to the fear of death. For some it is minor inconvenience, for others it is major problem that causes suffering and reduces quality of life. And thus pain of IV cannulation interferes with the actual pain and problem of patient which may require the prompt treatment.

According to a report in 2006, there were 503,300 hospital stays with IV cannulated patients and noted an increase of nearly $80 \%$ since 1993 . More than $90 \%$ of the patients had IV cannula in general ward, and in post operative ward $100 \%$ of patients had IV cannula line. In comparison, 56.5\% of male patients and rest of them were female and children. The cross sectional study results shows that complication of phlebitis rates reported for patients receiving intravenous therapy have been as high as $80 \%$. Other complications resulting from intravenous cannulation include thrombophlebitis, extravasations, and infection resulting from bacteraemia and septicaemia. ${ }^{5}$

\section{Problem statement}

A study to compare the effectiveness in reduction of pain level between simple intravenous cannulation and prosafety intravenous cannulation.

\section{Objectives of the study}

1. To assess the pain level among patients undergoing intravenous cannulation with simple IV cannula.

2. To assess the pain level among patients undergoing intravenous cannulation with pro safety IV cannula.

3. To compare the effect of simple IV cannula and pro safety cannula on pain level.

4. To determine the association between pain level and demographic variables of selected patients.

\section{Hypothesis}

$\mathbf{H}_{\mathbf{0}}$-There will no significant relationship between types of I.V. cannulation and pain level score at 0.05 level of significance.

\section{The Conceptual Framework}

The conceptual framework of the study is based on modified General System theory by Ludwig Von Bertanlanffy (1968).

\section{Research Methodology:-}

A quantitative research approach with True Experimental design was used for the study. Research study was conducted on May 2018 at selected hospitals of Gujarat state. A sample of 60 patients were selected using Non probability purposive sampling technique and samples are assigned using simple random technique for Simple IV cannula and Pro safety IV cannula.

\section{Tools:}

The tool consisted of three sections.

\section{Section - a:}

This section includes assessing Socio-demographic age, gender, family income, site of cannula insertion, size of cannula, number of prick, total number of hospital admission.

\section{Section - b:}

This section includes A Numerical Rating Scale was used to assess the pain level of patients and its shows the rating scale according to the pain level. 
1. : No Pain

2. 1-3 : Mild Pain

3. 4-6 : Moderate Pain

4. 7-9: Severe Pain

5. 10 : Worst Pain

\section{Results And Interpretations:-}

Analysis and interpretation of the data collected from 60 patients who underwent IV cannulation, to compare the effectiveness in reduction of pain level between simple intravenous cannulation and pro-safety intravenous cannulation. The data analysed by using descriptive and inferential statistics.

\section{Characteristics of demographic variables of old age people}

\section{Simple cannula}

In Simple IV cannula with regard to age majority of the subjects 13 (43.3\%) belongs to 41 - 45 years. With regards to gender 14(46.7\%) belong to Male, 16(53.3\%) belongs to female. With regard to Family income per month 13 (43.3\%) belongs to 5001 - 10000. With regard to Size of cannula 29 (96.7\%) had 20 gauze. With regard to Location of cannula attempt $10(33.3 \%)$ had IV cannula on dorsum of the right hand. With regard to Total number of days of hospital admission $29(96.7 \%)$ were admitted since < 3 days. With regard to Total number of attempt for IV cannulation $29(96.7 \%)$ for 1 time.

\section{Pro safety cannula}

In Pro safety IV cannula with regards to the age , 8 (26.7\%) belongs to 41 - 45 years, 8 (26.7\%) belongs to 46 - 50 years. With regard to Gender $17(56.7 \%)$ belong to Male, 13(43.3\%) belongs to female. With regard to Family income per month $11(36.7 \%)$ belongs to $5001-10000$. With regard to Size of cannula $30(100.0 \%)$ had 20 gauze. With regard to Location of cannula attempt $9(30.0 \%)$ had IV cannula on dorsum of the right hand. With regard to Total number of days of hospital admission $22(73.3 \%)$ were admitted since $<3$ days. With regard to Total number of attempt for IV cannulation $29(96.7 \%)$ for 1 time.

\section{Comparison of pain score of simple IV cannula and Pro safety IV cannula in patients undergoing IV} cannulation

In order to compare the pain score of simple IV cannula and Pro safety IV cannula in patients undergoing IV cannulation unpaired $\mathrm{T}$ test was used. The mean difference in pain score of simple IV cannula is higher than the mean difference in pain score of Pro safety IV cannula $(4.3>2.67)$. The above results indicates that the pro safety IV cannulation is effective in reducing pain compare to simple IV cannulation. Hence null hypothesis $\mathrm{H}_{0}$ was rejected.

Comparison between the effect of simple IV cannula and pro safety cannula on pain

\begin{tabular}{|c|c|c|c|c|c|c|}
\hline & Mean & Mean difference & SD & Df & $\begin{array}{c}\text { Independent } \\
\text { ' } \mathrm{t} \text { ' value }\end{array}$ & $\mathrm{p}$ value \\
\hline $\begin{array}{c}\text { Simple IV } \\
\text { Cannulation }\end{array}$ & 4.3 & 1.63 & 0.95 & 58 & 6.49 & $<0.05$ \\
\cline { 1 - 5 } $\begin{array}{c}\text { Pro safety IV } \\
\text { Cannulation }\end{array}$ & 2.67 & & 0.99 & & & \\
\cline { 6 - 7 } & & & & & \\
\hline
\end{tabular}

Table I. Illustrates that the mean pain score (2.67) with pro safety IV cannulation was lesser than the mean pain score (4.3) with simple IV cannulation with the mean difference of was (1.63). The unpaired test value was computed to determine and compare the effect of simple IV cannulation and pro safety IV cannulation on pain. Unpaired t calculated value is $6.49 * \mathrm{p}<0.05$ is significant at $0.05 \%$ level. This indicates that the pro safety IV cannulation is effective in reducing pain compare to simple IV cannulation.

Association between simple IV cannulation pain level and demographic variables $\mathrm{N}=30$

\begin{tabular}{|c|c|c|c|c|c|c|c|}
\hline Demographic variables & $\begin{array}{c}\text { Mil } \\
\text { d }\end{array}$ & $\begin{array}{c}\text { Moderat } \\
\text { e pain }\end{array}$ & $\begin{array}{c}\chi_{2} \\
\text { f } \\
\text { Cailculate } \\
\text { d value }\end{array}$ & $\begin{array}{c}\chi^{2} \\
\text { Tabulate } \\
\text { d value }\end{array}$ & $\begin{array}{c}\text { Remark } \\
\text { s }\end{array}$ \\
\hline
\end{tabular}




\begin{tabular}{|c|c|c|c|c|c|c|}
\hline & $\mathbf{n}$ & & & & & \\
\hline \multicolumn{3}{|l|}{ 1.Age in years } & \multirow[t]{7}{*}{5} & \multirow[t]{7}{*}{1.63} & \multirow[t]{7}{*}{11.7} & \multirow[t]{7}{*}{$\mathrm{NS}$} \\
\hline - 21-25 years & 0 & 1 & & & & \\
\hline - $\quad 26-30$ years & 0 & 2 & & & & \\
\hline - $\quad 31-35$ years & 1 & 5 & & & & \\
\hline - $\quad 36-40$ years & 0 & 3 & & & & \\
\hline - $41-45$ years & 3 & 10 & & & & \\
\hline - $46-50$ years & 1 & 4 & & & & \\
\hline \multicolumn{7}{|l|}{ 2.Gender } \\
\hline - $\quad$ Male & 2 & 12 & \multirow[t]{2}{*}{1} & \multirow[t]{2}{*}{0.11} & \multirow[t]{2}{*}{3.84} & \multirow[t]{2}{*}{ NS } \\
\hline - $\quad$ Female & 3 & 13 & & & & \\
\hline \multicolumn{7}{|l|}{ 3.Family income per month } \\
\hline$\cdot \quad<5000$ & 1 & 3 & \multirow[t]{4}{*}{3} & \multirow[t]{4}{*}{0.62} & \multirow[t]{4}{*}{7.84} & \multirow[t]{4}{*}{ NS } \\
\hline - $5001-10000$ & 2 & 11 & & & & \\
\hline - $10001-20000$ & 1 & 3 & & & & \\
\hline$\cdot \quad>20000$ & 1 & 8 & & & & \\
\hline \multicolumn{7}{|l|}{ 4.Size of cannula } \\
\hline - 18 gauze & 0 & 1 & \multirow[t]{2}{*}{1} & \multirow{2}{*}{0.21} & \multirow[t]{2}{*}{3.84} & \multirow[t]{2}{*}{ NS } \\
\hline - 20 gauze & 5 & 24 & & & & \\
\hline \multicolumn{7}{|l|}{ 5.Location of cannula attempt } \\
\hline - $\quad$ Dorsum of the left hand & 0 & 9 & \multirow[t]{4}{*}{3} & \multirow[t]{4}{*}{3.68} & \multirow[t]{4}{*}{7.84} & \multirow[t]{4}{*}{ NS } \\
\hline - $\quad$ Dorsum of the right hand & 2 & 8 & & & & \\
\hline - $\quad$ Antecubital fossa of the left arm & 2 & 7 & & & & \\
\hline - $\quad$ Antecubital fossa of the right arm & 1 & 1 & & & & \\
\hline \multicolumn{7}{|l|}{ 6.Total number of days of hospital admission } \\
\hline - $\quad<3$ days & 5 & 24 & \multirow[t]{2}{*}{1} & \multirow[t]{2}{*}{0.21} & \multirow[t]{2}{*}{3.84} & \multirow[t]{2}{*}{ NS } \\
\hline - $3-6$ days & 0 & 1 & & & & \\
\hline \multicolumn{7}{|l|}{ 7.Total number of attempt for IV cannulation } \\
\hline - 1 & 5 & 24 & 1 & 0.21 & 3.84 & NS \\
\hline $\begin{array}{ll} & 2 \\
\end{array}$ & 0 & 1 & & & & \\
\hline
\end{tabular}

NS: Non significant

S: Significant

Table II. a, shows that the calculated chi square value was less than the chi square tabulated value at 0.05 level of significance for all the selected demographic variables like age, gender, family income, size of cannula, location of cannula attempt, Total number of days of hospital admission and total number of attempt for IV cannulation.

Association between pro safety IV cannulation pain level and demographic variables $\mathrm{N}=30$

\begin{tabular}{|c|c|c|c|c|c|c|}
\hline $\begin{array}{c}\text { Demographic } \\
\text { variables }\end{array}$ & $\begin{array}{l}\text { Mild } \\
\text { pain }\end{array}$ & $\begin{array}{l}\text { Moderate } \\
\text { pain }\end{array}$ & Df & $\begin{array}{c}\chi 2 \text { Calculated } \\
\text { value }\end{array}$ & $\begin{array}{c}\chi 2 \text { Tabulated } \\
\text { value }\end{array}$ & Remarks \\
\hline \multicolumn{7}{|l|}{ 1.Age in years } \\
\hline - 21-25 years & 3 & 0 & \multirow[t]{6}{*}{5} & \multirow[t]{6}{*}{7.34} & \multirow[t]{6}{*}{11.07} & \multirow[t]{6}{*}{$\mathrm{NS}$} \\
\hline - 26-30 years & 3 & 1 & & & & \\
\hline - $31-35$ years & 2 & 0 & & & & \\
\hline - $36-40$ years & 5 & 0 & & & & \\
\hline - $41-45$ years & 7 & 1 & & & & \\
\hline - $\quad 46-50$ years & 4 & 4 & & & & \\
\hline \multicolumn{7}{|l|}{ 2.Gender } \\
\hline - $\quad$ Male & 11 & 6 & \multirow[t]{2}{*}{1} & \multirow[t]{2}{*}{5.74} & \multirow[t]{2}{*}{3.84} & \multirow[t]{2}{*}{$\mathrm{S}$} \\
\hline - $\quad$ Female & 13 & 0 & & & & \\
\hline \multicolumn{7}{|c|}{ 3.Family income per month } \\
\hline$\cdot \quad<5000$ & 3 & 0 & \multirow[t]{2}{*}{3} & \multirow[t]{2}{*}{3.89} & \multirow[t]{2}{*}{7.84} & \multirow[t]{2}{*}{$\mathrm{NS}$} \\
\hline - $\quad 5001-10000$ & 10 & 1 & & & & \\
\hline
\end{tabular}




\begin{tabular}{|c|c|c|c|c|c|c|}
\hline • $\quad 10001-20000$ & 4 & 3 & & & & \\
\hline - $\quad>20000$ & 7 & 2 & & & & \\
\hline \multicolumn{7}{|l|}{ 4.Size of cannula } \\
\hline • 20 gauze & 24 & 6 & - & - & - & NA \\
\hline \multicolumn{7}{|c|}{ 5.Location of cannula attempt } \\
\hline $\begin{array}{l}\text { - Dorsum of the left } \\
\text { hand }\end{array}$ & 6 & 0 & \multirow[t]{4}{*}{3} & \multirow[t]{4}{*}{2.77} & \multirow[t]{4}{*}{7.84} & \multirow[t]{4}{*}{ NS } \\
\hline $\begin{array}{l}\text { Dorsum of the } \\
\text { right hand }\end{array}$ & 6 & 3 & & & & \\
\hline $\begin{array}{l}\text { Antecubital fossa } \\
\text { of the left arm }\end{array}$ & 6 & 1 & & & & \\
\hline $\begin{array}{l}\text { Antecubital fossa } \\
\text { of the right arm }\end{array}$ & 6 & 2 & & & & \\
\hline \multicolumn{7}{|c|}{ 6.Total number of days of hospital admission } \\
\hline - $\quad<3$ days & 18 & 4 & \multirow[t]{2}{*}{1} & \multirow[t]{2}{*}{0.17} & \multirow[t]{2}{*}{3.84} & \multirow[t]{2}{*}{ NS } \\
\hline - $3-6$ days & 6 & 2 & & & & \\
\hline \multicolumn{7}{|c|}{ 7.Total number of attempt for IV cannulation } \\
\hline - 1 & 23 & 6 & \multirow[t]{2}{*}{1} & \multirow[t]{2}{*}{0.26} & \multirow[t]{2}{*}{3.84} & \multirow[t]{2}{*}{$\mathrm{NS}$} \\
\hline - 2 & 1 & 0 & & & & \\
\hline
\end{tabular}

NS: Non significant

S: Significant

Table II. b, shows that the calculated chi square value was less than the chi square tabulated value at 0.05 level of significance for most of the selected demographic variables like age, family income, size of cannula, location of cannula attempt, Total number of days of hospital admission and total number of attempt for IV cannulation. Whereas it was found that it is associated with gender.

\section{Conclusion:-}

Nurses are key persons of a health team, who play a major role in the health promotion and maintenance; it is practicing that the researchers generally integrate findings in to practice. Nurses can play a valuable role in minimizing the associated physical discomfort and complications that patients may experience as a having pro safety IV cannulation through maintaining their knowledge and skills. Use of pro safety cannula may also help in prevention of Needle stick injury and exposure to blood than the simple IV cannula which is helpful for nursing personal.

\section{Conflict of Interest:}

None

Source of Funding:

No separate funding was received for this study.

Ethical Clearance:

The ethical clearance obtained from our Institute (CHARUSAT University, Changa ).

\section{References:-}

1. Jisha P. Sundaran, Fareha Khan, Priyanka Bansal, Jyotsana. An Experimental Study to Assess the Effectiveness of Valsalva Maneuver Prior to Intravenous Cannulation on Pain Perception among Patients Undergoing Venous Cannulation at HAHC Hospital in Delhi [ Abstract ] 2016 [ cited on 8 June 2017 ]:5 (2): 1 - 6. Available

from:https://www.researchgate.net/publication/308122489_An_Experimental_Study_to_Assess_the_Effectiven ess_of_Valsalva_Maneuver_Prior_to_Intravenous_Cannulation_on_Pain_Perception_among_Patients_Undergo ing_Venous_Cannulation_at_HAHC_Hospital_in_Delhi

2. Denise .F. Polit \& Cheryl Tatano Beck, Nursing Research, Generating \& Assessing Practice, eighth edition. Lippincott Williams \& Wilkins.2008. 
3. Cleary M. Peripheral intravenous cannulation.[ Online ] 1991[ cited on 5 June 2017 ]:20: 1285-1288. Available from:http://europepmc.org/abstract/med/1953471.

4. Gil Z Shlamovitz, MD, FACEP; Chief Editor: Vincent Lopez Rowe. Intravenous Cannulation. Medscape. [ Online ] Updated: Apr 10, 2017 [ cited on 16 June 2017 ]. Available from:http://emedicine.medscape.com/article/1998177-overview.

5. Collignon P. Intravascular catheter incidence and associated sepsis: a common problem. The Australian study on intravascular catheter-associated sepsis. Med J Aust [ ABSTRACT ] 1994; 161:374-378. [ cited on 14 June 2017 ]. Available from:https://link.springer.com/article/10.1007/s100960050001. 